\title{
TINGKAT KEPATUHAN TERAPI PASIEN GAGAL GINJAL KRONIK YANG MENGALAMI DEPRESI
}

\author{
Havizur Rahman ${ }^{1}$, Helmi Arifin ${ }^{2}$, Arina Widya Murni ${ }^{3}$ \\ ${ }^{1}$ Universitas Jambi, ${ }^{2}$ Universitas Andalas, ${ }^{3}$ RSUP DR M. Djamil Padang \\ Email : havizurrahman27@unia.ac.id
}

\begin{abstract}
Depression is known to be one of the causes of noncompliance therapy. This study aims to determine the correlation between depression with compliance of chronic renal failure patients. The method in this study is cross-sectional. Data is collected by judgment sampling. Depression level is assessed by using the Beck Depression Inventory-II (BDI- II). Compliance level is assessed by using the morisky scale. The result shows an average compliance level of chronic renal failure patients is included in high compliance category (53.03\%). It is found that there is not a correlation between depression and compliance of chronic renal failure patients ( $p>0.05)$. it is concluded that there is no correlation between depression and compliance of chronic renal failure patients.
\end{abstract}

Key words: Depression, compliance, chronic renal failure.

\section{PENDAHULUAN}

Gagal ginjal kronis adalah suatu sindrom klinis yang disebabkan penurunan fungsi ginjal yang bersifat menahun, berlangsung progresif dan cukup lanjut. Gagal ginjal kronis terjadi ketika ginjal tidak mampu mengangkut sampah metabolik tubuh atau melakukan fungsi regulernya untuk mengeksresi sisa metabolisme dari dalam tubuh sehingga terjadi gangguan fungsi endokrin dan metabolisme, gangguan keseimbangan cairan, elektrolit, serta asam basa. $^{1}$

Depresi adalah gangguan psikiatri yang menonjolkan mood sebagai masalahnya, dengan berbagai gambaran klinis yakni gangguan episode depresif, gangguan sistemik, gangguan depresif mayor dan gangguan depresif unipolar serta bipolar. ${ }^{2}$ Depresi merupakan penyakit yang sering muncul terutama pada pasien penyakit kronis, salah satunya gagal ginjal kronik. ${ }^{3}$

Dari sebuah penelitian dari Universitas Indonesia menemukan bahwa prevalensi depresi pada pasien gagal ginjal kronik yang menjalani hemodialisis mencapai $31,1 \%$. Pada salah satu penelitian lain ditemukan $20-40 \%$ populasi yang sedang menjalani terapi dialysis mengalami depresi dan nilai tersebut dapat lebih tinggi pada pasien predialisis. ${ }^{4}$

Etiologi depresi pada pasien gagal ginjal sangat komplek. Penurunan fungsi ginjal diikuti dengan kerusakan nefron. Selanjutnya terjadi peningkatan tekanan dan aliran darah ke kapiler glomerulus sebagai usaha kompensasi fungsi ginjal yang hilang sehingga terjadi hipertrofi atau perubahan struktur dan fungsi nefron. Proses ini diperantarai oleh molekul vasoaktif salah satunya sitokin. Stimulasi dari sitokin akan mempengaruhi jumlah serotonin, yang merupakan prekusor terjadinya depresi. Peningkatan aktifitas renin- 
angiostensin aldosterone intrarenal ikut memberikan kontribusi terjadinya hiperfiltrasi, sclerosis dan progresifitas penurunan fungsi ginjal. $^{5}$

Ketidakpatuhan terapi (non-
compliance) pada seseorang dapat
kesalahan dalam penilaian efektivitas obat, uji diagnostic tambahan, perubahan atau penggantian obat, dan perawatan di rumah sakit yang sebenarnya tidak diperlukan. ${ }^{6}$ Ketidakpatuhan berobat akan mengakibatkan risiko yang tidak diinginkan seperti kunjungan ke dokter berulang kali, perubahan dan penambahan resep, perburukan klinis, serta masa perawatan menjadi lebih panjang. ${ }^{7}$ Kepatuhan pasien menurun seiring dengan bertambahnya jumlah obat yang digunakan. ${ }^{8}$ Sejumlah penelitian telah mencoba untuk mengidentifikasi penyebab dari ketidakpatuhan dan banyak faktor yang telah teridentifikasi salah satu diantaranya yaitu depresi. $^{9}$

\section{METODE PENELITIAN}

Jenis Penelitian

Metode penelitian yang digunakan adalah cross sectional menggunakan data primer, dengan teknik pengambilan data judgment sampling.

\section{Pengukuran Tingkat Depresi dan Tingkat Kepatuhan.}

Dalam mengukur tingkat depresi menggunakan Beck Depression Inventory-II (BDI- II). Setiap pernyataan memilki score, jika jumlah score $>13$ maka pasien digolongkan ke dalam depresi. Penilaian tingkat kepatuhan menggunakan skala morisky. Pasien dikatakan memilki kepatuhan rendah jika jumlah score 3-4, kepatuhan sedang 1-2, dan 0 menunjukkan kepatuhan tinggi.

\section{Sumber data \\ Sumber data meliputi: rekam medik semua pasien gagal ginjal kronis dan observasi langsung kepada pasien melalui wawancara atau pengisian form Beck Depression Inventory (BDI)-II, Morisky.}

\section{Analisis Data}

Data ditampilkan dalam bentuk tabel (Means \pm Standart Deviasi dan persentase (\%)). Kemudian data diolah menggunakan SPSS, karena melihat hubungan variable dependent dan independent maka digunakan uji korelasi, dan jika ada korelasi maka dilanjutkan dengan uji regresi sederhana. Untuk uji kenormalan/distribusi data menggunakan uji komogorov smirnov. Jika data terdistribusi normal maka menggunakan uji korelasi pearson dan jika tidak terdistribusi normal maka menggunakan uji spearman untuk melihat korelasi antara depresi dengan tingkat kepatuhan terapi. Jika koefisien korelasi $>r$ tabel dan sig $<0,05$, berarti ada hubungan, dan sebaliknya. Jika bertanda negatif maka hubungan antar variable berbanding terbalik. Untuk uji regresi sederhana, jika niali $R$ mendekati 1 , menunjukan kekuatan hubungan antar variable dan perbandingan nilai $F$ dengan $F$ tabel untuk prediksi apakah persamaan garis regresi dapat digunakan atau tidak. Jika F> F tabel maka persamaan resgresi dapat digunakan untuk prediksi dan sebaliknya. 
Tingkat kepatuhan terapi pasien gagal ginjal kronik yang mengalami depresi.

HASIL DAN PEMBAHASAN

Gambaran derajat depresi pasien gagal ginjal kronik

Tabel 1. Tingkat depresi pasien gagal ginjal kronik

\begin{tabular}{ccc}
\hline Tingkat Depresi & Jumlah $(\mathbf{n})$ & Persentase (\%) \\
\hline Depresi & 16 & $24,24 \%$ \\
Non-depresi & 50 & $75,76 \%$ \\
\hline
\end{tabular}

Pada penelitian ini ditemukan jumlah pasien non-depresi lebih banyak dari pasien depresi. Penderita depresi ditemukan sebanyak 16 pasien $(24,24 \%)$ dan non depresi 50 pasien $(75,76 \%)$.

Depresi merupakan penyakit yang sering muncul terutama pada pasien penyakit kronis, salah satunya gagal ginjal kronik. Pada penelitian ini dari 66 pasien yang didiagnosa gagal ginjal kronik 16 (22,24\%) pasien menderita depresi. Pengukuran tingkat depresi menggunakan skala BDI-II dinyatakan depresi jika score $>13$. Pada penelitian lain ditemukan $20-40 \%$ populasi yang sedang menjalani terapi dialisis mengalami depresi dan nilai tersebut dapat lebih tinggi pada pasien predialisis. $^{10}$

Pada penelitian lain menggunakan skala yang sama dilaporkan $30-50 \%$ pasien dialysis mengalami depresi ${ }^{11}$ dan hasil laporan $^{12}$ ditemukan penderita depresi pada pasien yang menjalani hemodialisa $20-30 \%$. Pasien hemodialisa menderita depresi sebanyak $29 \%$ dan $27 \%$ mengalami gangguan ansietas. ${ }^{13}$ Dilakukan perbandingan antara pasien hemodialisa dan peritoneal dialisa, hasilnya ditemukan dari 43 pasien yang menjalani peritoneal dialisis dan 43 hemodialisis dilaporkan prevalensi depresi $26,1 \%$ pada pasien hemodialisis dan $25,4 \%$ pada grup peritoneal dialisis. ${ }^{14}$

Pada studi dengan menggunakan parameter selain BDI-II, seperti yang dilakukan oleh DOPPS dengan partisipan >9000 orang pada 12 negara dilaporkan pasien depresi sebanyak $43 \%$ menggunakan CES-D sebagai skala mengukur tingkat depresi. ${ }^{15}$ Pada studi lain dengan questioner yang sama pada pasien hemodialisis dilaporkan pasien depresi $26,7 \%{ }^{16}$ Depresi ditemukan pada 57 pasien $(23,7 \%)$ dialisis dengan menggunakan CES-D. ${ }^{10}$ Studi longitudinal pada pasien hemodialisis, dilaporkan $29 \%$ pasien depresi dengan menggunakan skala SCID sebagai parameter ukur. Menariknya, pada 16 bulan berikutnya ditemukan $43 \%$ pasien didiagnosa depresi. Depresi yang menetap berhubungan dengan penerimaan pasien terhadap status kesehatannya dan riwayat depresi. ${ }^{13}$

\section{Hubungan depresi dengan tingkat kepatuhan pasien}

Tabel 2. Hubungan tingkat depresi dengan tingkat kepatuhan pasien

\begin{tabular}{ccccccc}
\hline & \multicolumn{9}{c}{ Tingkat Depresi } & Sig & Korelasi \\
\cline { 2 - 5 } & \multicolumn{2}{c}{ Non Depresi } & \multicolumn{2}{c}{ Depresi } & & \\
\cline { 2 - 5 } & $\mathbf{n}$ & $\%$ & $\mathbf{n}$ & $\%$ & & \\
\hline Kepatuhan Tinggi & 25 & $(37,9 \%)$ & 10 & $(15,1)$ & \multirow{2}{*}{0,008} \\
Kepatuhan Sedang & 11 & $(16,7 \%)$ & 0 & $(0 \%)$ & 0,948 & \multirow{2}{*}{0,008} \\
Kepatuhan Rendah & 13 & $(19,7 \%)$ & 6 & $(9,1 \%)$ & & \\
\hline
\end{tabular}


Kepatuhan pasien meminum obat dikelompokkan kepada 3 tingkatan yaitu kepatuhan tinggi, kepatuhan sedang, dan kepatuhan rendah. Pada penelitian ini 53\% partisipan termasuk kelompok dengan kepatuhan tinggi, kepatuhan sedang $16.7 \%$ sedangkan kepatuhan rendah $28.8 \%$. pasien non-depresi dengan kepatuhan tinggi sebanyak $37,9 \%$, kepatuhan sedang $16,7 \%$, dan kepatuhan rendah 19,7\%. Sedangkan pada pasien depresi dengan kepatuhan tinggi sebanyak $15,1 \%$, kepatuhan sedang $0 \%$, dan kepatuhan rendah $9,1 \%$.

Dengan menggunakan uji Kolmogorov smirnov untuk melihat distribusi data diperoleh nilai sig< 0.05 , yang berarti data tidak terdistribusi normal. Sehingga digunakan uji statistic non parametrik yaitu uji spearman untuk melihat korelasi antara tingkat depresi dengan tingkat kepatuhan pasien. Hubungan depresi dengan tingkat kepatuhan dianalisa menggunakan uji korelasi spearman, ditemukan bahwa tidak ada hubungan antara depresi dengan kepatuhan pada pasien gagal ginjal kronik ( $p=0,948>0,05)$.

Depresi memiliki hubungan yang kuat dengan banyak penyakit kronik, salah satunya penyakit ginjal kronik. ${ }^{3}$ Depresi merupakan salah satu faktor penyebab ketidakpatuhan pasien dalam pengobatan. ${ }^{9}$ Pada salah satu penelitian mengatakan pasien depresi lebih tidak patuh terhadap pengobatan dari pada pasien non-depresi. ${ }^{17}$ Literatur lain juga mengidentifikasi depresi sebagai faktor resiko ketidakpatuhan terapi. ${ }^{18}$

Berdasarkan hasil temuan penelitian mengenai hubungan tingkat kepatuhan dengan depresi menggunakan analisa uji korelasi spearman, ditemukan bahwa tidak ada hubungan antara depresi dengan kepatuhan pada pasien gagal ginjal kronik ( $p$ $>0,05)$. Kepatuhan pasien tidak tergantung dari depresi atau tidaknya pasien, ini bisa disebabkan oleh faktor budaya dan dukungan/perhatian dari keluarga. Pada salah satu penelitian mengatakan depresi memilki pengaruh yang kuat berkontribusi menurunkan kepatuhan terapi pada pasien gagal ginjal terminal yang dilakukan hemodialisis atau transplatasi organ ${ }^{13}$. Cohen $^{19}$ melaporkan dengan populasi yang pada umumnya adalah pasien dengan kulit hitam, ditemukan depresi merupakan faktor resiko ketidakpatuhan pasien dalam pengobatan meskipun hanya dalam persentase yang kecil. Perbedaan hasil dari tiap penelitian kemungkinan disebabkan oleh perbedaan demografi atau sample yang heterogen.

Depresi dapat mempengaruhi tingkat kepatuhan pasien dalam pengobatan terutama pada pasien dialisis. ${ }^{20}$ Depresi dapat memberikan pengaruh yang buruk terhadap kehidupan pasien, seperti menurunkan kualitas hidup dan kepatuhan pasien dalam pengobatan. ${ }^{21}$ Pada pasien hemodialisis dengan depresi memiliki kualitas hidup yang lebih rendah, serta dapat menyebabkan penurunan kepatuhan pasien dalam pengobatan. ${ }^{16}$

\section{KESIMPULAN}

Jumlah pasien gagal ginjal kronik yang menderita depresi sebanyak 22,24\%. Tingkat kepatuhan pasien gagal ginjal yang ditemukan termasuk kedalam kategori kepatuhan tinggi. Tidak ditemukan hubungan antara depresi dengan tingkat kepatuhan pada pasien gagal ginjal.

\section{DAFTAR PUSTAKA}

1. Sweetman SC. Martindale $6^{\text {th }}$ Ed. London: Pharmaceutical Press; 2009. 
2. Anonim. Pharmaceutical Care Untuk Penderita Gangguan Depresif. Direktorat Bina Farmasi Komunitas dan Klinik. Ditjen Bina Kefarmasian dan Alat Kesehatan. 2007.

3. Passik SD, Lundberg JC, Rosen FB, Kirsh. Factor Analysis Of The Zung SelfRating Depression Scale In A Large Ambulatory Sample. Psychosomatic. 2000; 41:121-127.

4. Zalai, M. Depressive Disorder In Patient With Chronic Kidney Disease. Primary psychiatry. 2008; 15(1):66-72.

5. Suharjono dan Rahardjo P. Artikel Diit Protein dan Ginjal. Cermin Dunia Kedokteran. 1987.

6. Simpson RJ. Challenges For Improving Medication Adherence. JAMA. 2006;296:2614-2616.

7. Winnick S, Lucas DO, Hartman AL, Toll D. How Do You Improve Compliance Pediatrics. 2005; 115:718-724

8. Vermeire E. Patient adherence to treatment: three decades of research. Journal of clinical pharmacy and therapeutics. $2001 ; 26: 331-342$.

9. Wiffen $\mathrm{P}$, Mitchell M, Snelling M, Stoner N. Oxford Handbook of Clinical Pharmacy. English: Oxford University Press. 2007.

10. Zalai M. Depressive Disorder in Patient With Chronic Kidney Disease. Primary psychiatry. 2008; 15(1):66-72.

11. Makara $M$ and Koslak A. Depression Symptoms Among Patiens With End Stage Renal Disease And Among Primary Health Care Patients. Archieve of psychiatry and psychotherapy. 2011; 3:510.

12. Brian T, Daniel E, Lena M. Depression and cognitive function in maintenance hemodialysis. Am J Kidney. 2010; 56(4):704-712.
13. Cukor D, Coplan J, Brown C, Friedman S, Cromwell A, Peterson RA, Kimmel PL. Depression And Anxiety In Urbanhemodialysis Patients. Clin J Am Soc Nephrol. 2007; 2(3): 484-90.

14. Mittal SK, Ahern L, Flaster E, Mittal VS, Maesaka JK, Fishbane S. Self-Assessed Quality Of Life In Peritoneal Dialysis Patients. Am J Nephrol. 2001; 21(3):215220.

15. Lopes AA, Albert JM, Young EW. Screening For Depression In Hemodialysis Patients: Associations With Diagnosis, Treatment And Outcomes In The DOOPS. Kidney Int. 2004; 66(5):2047-2053.

16. Hedayati SS, Grambow SC, Szczech LA, Stechuchak KM, Allen AS, Bosworth HB. Physician-diagnosed Depression as a Correlate of Hospitalizations in Patients Receiving Long-Term Hemodialysis. Am J Kidney Dis. 2005; 46(4):642-649.

17. DiMatteo RM, Lepper HL, Croghan TW. Depression is A Risk Factor Fornoncompliance With Medical Treatment. Arch Intern Med. 2000; 160;2101-2107.

18. Johnson MO, Charlebois E, Morin SF. Effects Of A Behavioralintervention On Antiretroviral Medication Adherence Among People Livingwith HIV: The Healthy Living Project Randomized Controlled Study. J Acquirlmmune Defic Syndr. 2007; 46:574-580.

19. Cohen SD, Norris L, Acquaviv K. Screening, Diagnosis, And Treatmentof Depression In Patients With End-Stage Renal Disease. Clin J Am Soc Nephrol. 2007; 2: 1332-1342.

20. Kimmel PL. Depression In Patients With Chronic Renal Disease: What We Know And What We Need To Know. J Psychom Res. 2002; 53:951-956.

21. Rita. Depression In The Elderly On Hemodialysis For Chronic Renal Failure. Acta Paulista de Enfermagem.2009; 22:505-508. 